\title{
H1-9 Gene
}

National Cancer Institute

\section{Source}

National Cancer Institute. H1-9 Gene. NCI Thesaurus. Code C162867.

This gene is involved in histone-mediated processes during spermiogenesis. 